\title{
NANOS3 wt Allele
}

National Cancer Institute

\section{Source}

National Cancer Institute. NANOS3 wt Allele. NCI Thesaurus. Code C104840.

Human NANOS3 wild-type allele is located in the vicinity of 19p13.13 and is approximately

$4 \mathrm{~kb}$ in length. This allele, which encodes nanos homolog 3 protein, plays a role in maintaining germ cells in an undifferentiated state. 